OPEN ACCESS

Edited by: Steven L. Forman,

Baylor University, United States

Reviewed by:

Ilya Bindeman,

University of Oregon, United States

Christian Teyssier,

University of Minnesota Twin Cities,

United States

*Correspondence: C. Page Chamberlain chamb@stanford.edu

Specialty section:

This article was submitted to Quaternary Science, Geomorphology and Paleoenvironment, a section of the journal Frontiers in Earth Science

Received: 25 November 2020 Accepted: 05 March 2021 Published: 09 April 2021

Citation: Chamberlain $C P$, Ibarra $D E$, Kukla T, Methner KA and Gao Y (2021) Triple Oxygen Isotope Paleoaltimetry of Crystalline Rocks.

Front. Earth Sci. 9:633687.

doi: 10.3389/feart.2021.633687

\section{Triple Oxygen Isotope Paleoaltimetry of Crystalline Rocks}

\author{
C. Page Chamberlain ${ }^{1 *}$, Daniel E. Ibarra ${ }^{1,2,3}$, Tyler Kukla ${ }^{1}$, Katharina A. Methner ${ }^{1}$ and \\ Yuan $\mathrm{Gao}^{4}$
}

\begin{abstract}
${ }^{1}$ Department of Geological Sciences, Stanford University, Stanford, CA, United States, ${ }^{2}$ Department of Earth and Planetary Science, University of California, Berkeley, Berkeley, CA, United States, ${ }^{3}$ Institute at Brown for Environment and Society and the Department of Earth, Environmental and Planetary Science, Brown University, Providence, Rl, United States, ${ }^{4}$ Earth Sciences and Resources, China University of Geosciences (Beijing), Beijing, China
\end{abstract}

Triple oxygen isotopes of hydrothermally altered minerals from crystalline rocks can be used to determine past elevations of mountain ranges. This method uses all three isotopes of oxygen $\left({ }^{16} \mathrm{O},{ }^{17} \mathrm{O}\right.$, and $\left.{ }^{18} \mathrm{O}\right)$ to create arrays that can be extrapolated back to the meteoric water line. One advantage of this technique is that it relies only on oxygen isotopes in contrast to previous studies that use oxygen and hydrogen isotopes to determine the isotopic composition of meteoric waters. Our analysis suggests that hydrogen isotopes may exchange with ambient fluids. Triple oxygen isotopes provide an independent check on the reliability of hydrogen isotope studies.

Keywords: paleoaltimetry, triple oxygen isotopes, meteoric fluids, granites, Rocky Mountains

\section{INTRODUCTION}

With the advent of stable isotope paleoaltimetry over 20 years ago (Chamberlain et al., 1999; Garzione et al., 2000; Rowley et al., 2001), we now have excellent constraints on the topographic history of many of the world's mountain belts. This work builds on the well-known relationship between $\delta^{18} \mathrm{O}$ and $\delta \mathrm{D}$ of meteoric water and elevation (Dansgaard, 1964), which is governed by Rayleigh distillation as airmasses and resultant precipitation pass over a mountain range. Indeed, it was recognized very early on that the isotope composition of authigenic minerals could be used to determine past elevations (Taylor, 1974; Winograd et al., 1985; Lawrence and Rashkes Meaux, 1993), before the sub-field of paleoaltimetry was established. So where are we today?

At the root of stable isotope paleoaltimetry studies are the theoretical and experimental advances that allow for a deeper understanding of isotopic records and increased number of proxies for the isotopic composition of paleo-precipitation. On the theoretical side we now have excellent Rayleigh distillation models (Rowley et al., 2001), one-dimensional isotopic vapor transport models that allow for vapor recycling (Winnick et al., 2014) as well as orographic precipitation (Kukla et al., 2019), and isotopic enabled Global Climate Models (GCMs) (Ehlers and Poulsen, 2009). Although there are many complications with these types of models, including vapor recycling (Kukla et al., 2019), changing isotopic lapse rates with temperature (Poulsen and Jeffery, 2011), and mixing of different moisture sources (Caves Rugenstein and Chamberlain, 2018), to name a few, the modern isotopic lapse rates across Earth are remarkably constant except at high latitudes (Poage and Chamberlain, 2001). Thus, many studies employ multiple approaches to reconstruct past elevation of orogens-often with similar results (c.f. Mix et al., 2011 and Feng et al., 2013). On the experimental side researchers have developed oxygen isotopic proxies for carbonate in paleosols (Quade et al., 2007) and paleolake sediments (Davis et al., 2009), fossil teeth (Kohn et al., 2002), 
clay minerals (Chamberlain et al., 1999), and chert (Ibarra et al., 2021). For hydrogen isotopes we have the additional proxies such as hydrated volcanic glasses (Mulch et al., 2008; Cassel et al., 2009; Hudak and Bindeman, 2018), clay minerals (Capuano, 1992; Delgado and Reyes, 1996; Mulch et al., 2006), plant leaf waxes (Hren et al., 2010) and metamorphic micas (Mulch et al., 2004).

These authigenic mineral proxies allow determination of meteoric water isotopic values if the temperature of formation and the appropriate fractionation factor are known. It is, however, also possible to determine meteoric water values using two isotopic systems and arrays of mineral isotopic compositions and extrapolating these arrays to the meteoric water line. This approach typically uses hydrogen and oxygen isotopes of hydrothermally altered minerals (see Criss and Taylor, 1983) or hydrogen and oxygen isotopes of chert from evaporative lakes (Abruzzese et al., 2005) to determine the original meteoric waters that altered or formed these minerals. The one difficulty with this approach is that it requires that both the hydrogen and oxygen isotopes behave similarly during mineral formation, mineral alteration, cooling, etc., which for hydrogen may not be the case (Graham, 1981; Graham et al., 1987). Thus, there is considerable power in leveraging isotopic systems that only use one elementsuch as provided by the analysis of the three isotopes of oxygen $\left({ }^{16} \mathrm{O},{ }^{17} \mathrm{O},{ }^{18} \mathrm{O}\right)$.

Thus, this mini-review discusses the new proxy afforded by the use of all three isotopes of oxygen - or triple oxygen isotope paleoaltimetry. This new proxy is particularly useful for determining the paleoelevations of the crystalline cores of mountain ranges, but also can be used to back out original meteoric waters from lake sediments (Ibarra et al., 2021). Here we review the application of triple oxygen isotopes in hydrothermally altered crystalline rocks.

\section{TERMINOLOGY AND EQUATIONS}

Triple oxygen isotope studies use all three stable oxygen isotopes of oxygen $\left({ }^{16} \mathrm{O},{ }^{17} \mathrm{O}\right.$ and $\left.{ }^{18} \mathrm{O}\right)$. The method exploits the very small deviations from mass dependent fractionations that govern most processes on Earth (Sharp et al., 2018). These deviations are caused by kinetic effects, such as occur during evaporation from water body etc. (Barkan and Luz, 2005) and temperature dependent equilibrium process during isotope exchange reactions reactions (e.g., Sharp et al., 2016). The equation describing these deviations is given by:

$$
\triangle^{\prime 17} O=\delta^{\prime 17} O-\lambda_{R L} \times \delta^{\prime 18} O+\gamma
$$

In this equation $\triangle^{\prime 17} \mathrm{O}$ is called "Cap 17 " or "17 $\mathrm{O}$-excess" and is the deviation from the reference slope $\lambda_{R L}$ of the mass dependent line for Earth materials which is 0.528 (Miller, 2002; Pack and Herwartz, 2014; Sharp et al., 2018) and $\gamma$ is the $y$-intercept of this line (taken as zero). $\delta^{\prime 17} O$ and $\delta^{\prime 18} O$ are the linearized forms (Miller, 2002) of standard $\delta$-notation and is calculated by:

$$
\delta^{\prime x} O=1000 \ln \left(\frac{\delta^{x} O}{1000}+1\right)
$$

For a more detailed description of these equations see Sharp et al. (2018).

\section{PALEOALTIMETRY WITH TRIPLE OXYGEN ISOTOPES}

\section{Method and Example}

The use of triple oxygen isotopes for paleoaltimetry was inspired by Herwartz et al. (2015) (see also Zakharov et al., 2017), who used triple oxygen isotopes of hydrothermally altered rocks of Proterozoic age to determine the oxygen isotope composition of meteoric waters during Snowball Earth. The approach uses arrays of $\delta^{17} \mathrm{O}$ and $\delta^{18} \mathrm{O}$ of hydrothermally altered minerals created by varying water/rock ratios to extrapolate to the triple oxygen meteoric water line (e.g., Passey and Ji, 2019). The logical extension was to apply this approach to paleoaltimetry (Chamberlain et al., 2020).

The method is similar to that used for hydrogen and oxygen isotopes of hydrothermal systems used to determine the isotopic composition of ancient meteoric waters (Taylor, 1978). Yet, the use of triple oxygen uses only one element's isotopic system. The approach involves: 1) Targeting meteoric water hydrothermal systems that have varying degrees or water/rock interaction. This would include such samples as low ${ }^{18} \mathrm{O}$ granites (Taylor, 1978), detachment faults of metamorphic core complexes (Mulch et al., 2004), and fault zones, or even hydrothermal veins (Sharp et al., 2005). 2) Obtaining pure mineral separates of minerals that readily exchange with fluids such as altered feldspars. 3) Collecting $\Delta^{17} \mathrm{O}$ and $\delta^{18} \mathrm{O}$ with the precision necessary to build tight arrays in $\Delta^{\prime 17} \mathrm{O}-\delta^{18} \mathrm{O}$ space. 4) Extrapolation of a fitted line through this array, using water/rock equations for both $\delta^{17} \mathrm{O}$ and $\delta^{18} \mathrm{O}$ (Taylor, 1978), to the meteoric water line with the added and small water/rock equilibrium fractionation factor. An excellent example of this approach is given in Zakharov et al. (2019) who used triple oxygen isotopes to study fluidrock interaction in the well-known hydrothermal systems in Iceland. Through careful analysis of minerals and fluids they were able to demonstrate how triple oxygen can be used assess the complicated processes that occur in hydrothermal systemsthereby setting the stage too apply this approach to ancient hydrothermal systems. We recently used (Chamberlain et al., 2020) this approach to determine the Eocene meteoric waters of the classic hydrothermal systems of the Idaho Batholith (Criss and Taylor, 1983).

The Cretaceous Idaho Batholith and later Eocene plutonic and volcanic rocks lies in the core of the northern Rocky Mountains with intermontane basins on both flanks (Figure 1). This area has been the subject of numerous paleoaltimetry studies of both the flanking basins and crystalline core. While most of the paleoaltimetry estimates come from clay and carbonate in paleosols and lake sediments (e.g., Kukla et al., 2021) the elevation estimates for the crystalline core rely almost exclusively on hydrogen isotopes of metamorphic (McFadden et al., 2015) and igneous micas (Criss and Taylor, 1983). The Eocene plutons created large Eocene (between 45 and 37 $\mathrm{Ma}$ ) meteoric hydrothermal systems that exchanged with the 


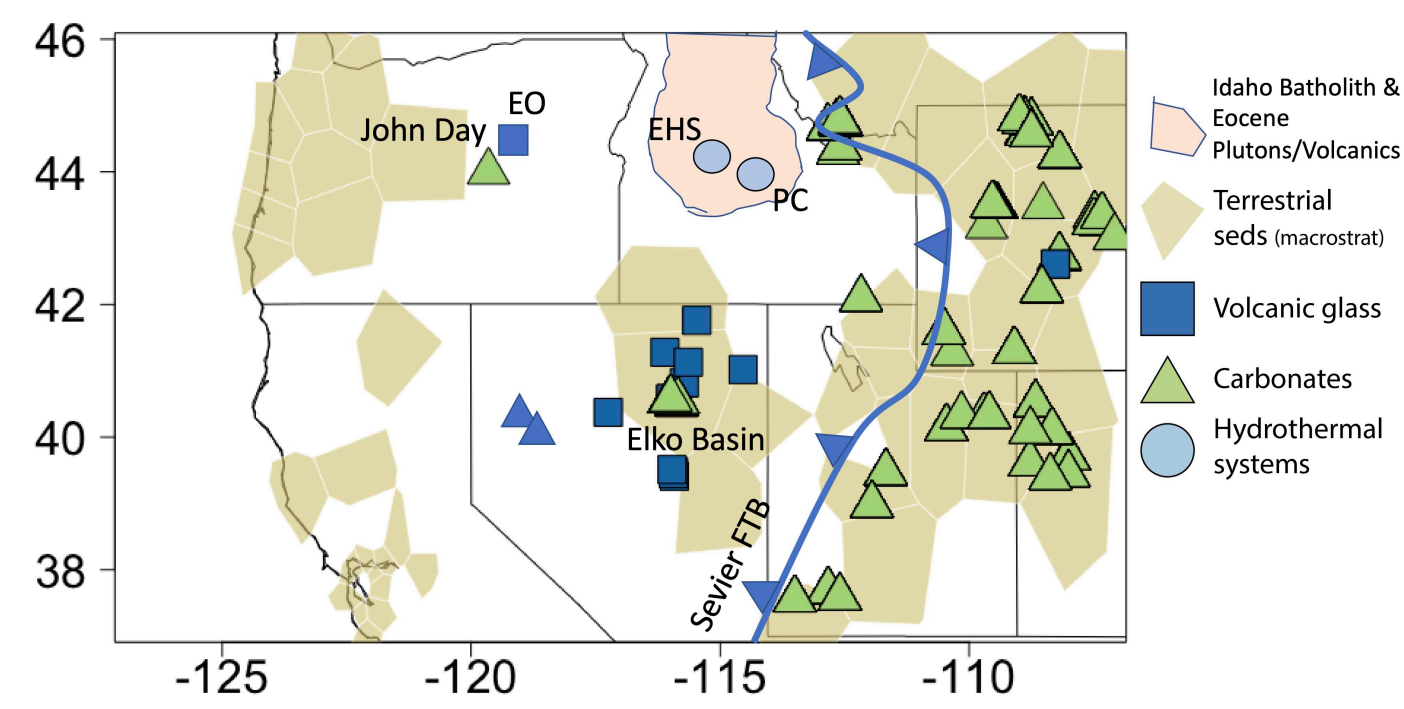

FIGURE 1 | Map of the Idaho batholith and Eocene plutons and volcanics and surrounding Eocene basins. Shown are the sites sampled for paleoaltimetry analysis for the Eocene. The triple oxygen isotope study of the Eocene hydrothermal system (Chamberlain et al., 2020) is given as the dot (EHS), the Pioneer core complex (PC; from McFadden et al., 2015), and the Early Oligocene volcanic glass in Blue Mountains (EO; from Bershaw et al., 2019). Shown is the eastern margin of the Sevier fold and thrust belt (Sevier FTB).

granites resulting in low ${ }^{18} \mathrm{O}$ minerals and rocks. As such, this represents an ideal target for triple oxygen isotope studies (Chamberlain et al., 2020), with the added benefit that these results are directly comparable to nearby hydrogen isotope paleoaltimetry studies.

There are two key results of our dataset from the Eocene plutons (Figure 2). First, the $\Delta^{\prime 17} \mathrm{O}$ and $\delta^{\prime 18} \mathrm{O}$ of hydrothermally altered feldspars form arrays that allow for extrapolation to the meteoric water line. Second, in contrast, the more resistant quartz samples are minimally altered from their original igneous values and, thus, provide no leverage on determining the composition of meteoric waters. These two results are similar to those found by Taylor $(1974,1978)$ that feldspar is more likely to exchange with later fluids than the more resistant quartz. Yet, with the addition of ${ }^{17} \mathrm{O}$ we have the leverage to determine the isotopic composition of the fluid using oxygen isotope values alone.

Based on this analysis the $\delta^{18} \mathrm{O}$ of the Eocene meteoric waters is relatively low $(-12 \pm 1 \%$ ) indicating high Eocene elevations (Chamberlain et al., 2020). But, how does this result compare to the results using hydrogen isotope analyses?

\section{Hydrogen Exchange Problems}

One key advantage of the triple oxygen isotope method for paleoaltimetry is that this approach only relies on one isotopic system $(\mathrm{O})$ and is independent of hydrogen that may exchange later with the environment. To test this idea, we (Chamberlain et al., 2020) analyzed the hydrogen isotopes of coexisting biotite in these samples and arrive at a $\delta^{18} \mathrm{O}=-15.3 \pm 1.12 \%$, which is $3 \%$ lower than the results from triple oxygen isotope analysis of the same rocks and similar to the value derived by Criss and Taylor (1983). This difference strongly suggests that the biotites we have measured have undergone later hydrogen exchange. The concept of hydrogen exchange after mineral formation was the subject of numerous studies over 40 years ago and was demonstrated to occur in many hydrous minerals including micas (O’Neil and Kharaka, 1976; Graham, 1981; Graham et al., 1987). Moreover, Graham (1981) showed that hydrogen continued to exchange with ambient fluids while cooling to temperatures between 300 and $100^{\circ} \mathrm{C}$. Further, O'Neil and Kharaka (1976) suggested that hydrogen exchange is independent of oxygen exchange and may be occurring by proton diffusion rather than by $\mathrm{OH}^{-}$groups or $\mathrm{H}_{2} \mathrm{O}$ molecules. Our work on triple oxygen confirms this conclusion.

This result indicates that paleoaltimetry estimates based on hydrogen isotopes may be inaccurate. For example, using the Eocene lapse rate of Rowley et al. (2001) (approximately $2.8 \%$ o $/ \mathrm{km}$ but changes with elevation becoming shallower at high elevations) the calculated elevation from the triple oxygen isotope data is $3.11 \mathrm{~km}+0.31 /-3.8(1 \sigma)$. In contrast, the $\mathrm{dD}$ versus $\delta^{18} \mathrm{O}$ of biotite gives higher elevations of $4.46 \mathrm{~km}+0.60 /-3.6$ $(1 \sigma)$. The lower elevations given by triple oxygen isotope analysis are also inconsistent with other elevation estimates based on hydrogen isotope measurements made on nearby metamorphic core complexes. McFadden et al. (2015) used hydrogen isotopes of micas from the detachment zone of the 38 to $37 \mathrm{Ma}$ core complex to the west of the area studied by Chamberlain et al. (2020) and determined a $\delta^{18} \mathrm{O}$ of $-16 \%$ for the meteoric water, which gives a higher elevation of $4.74 \mathrm{~km}+0.64 /-0.49$. In addition, hydrogen isotope measurements of volcanic glasses just west of the study area give earliest Oligocene $(32.7 \mathrm{Ma})$ meteoric water equivalent $\delta^{18} \mathrm{O}$ values of $-17 \%$ (Bershaw et al., 2019). These authors argue that the low $\delta^{18} \mathrm{O}$ waters reflect a high elevation proto-Cascades in Oregon. Since the Cascade mountains intercept airmasses upstream of the study area of 


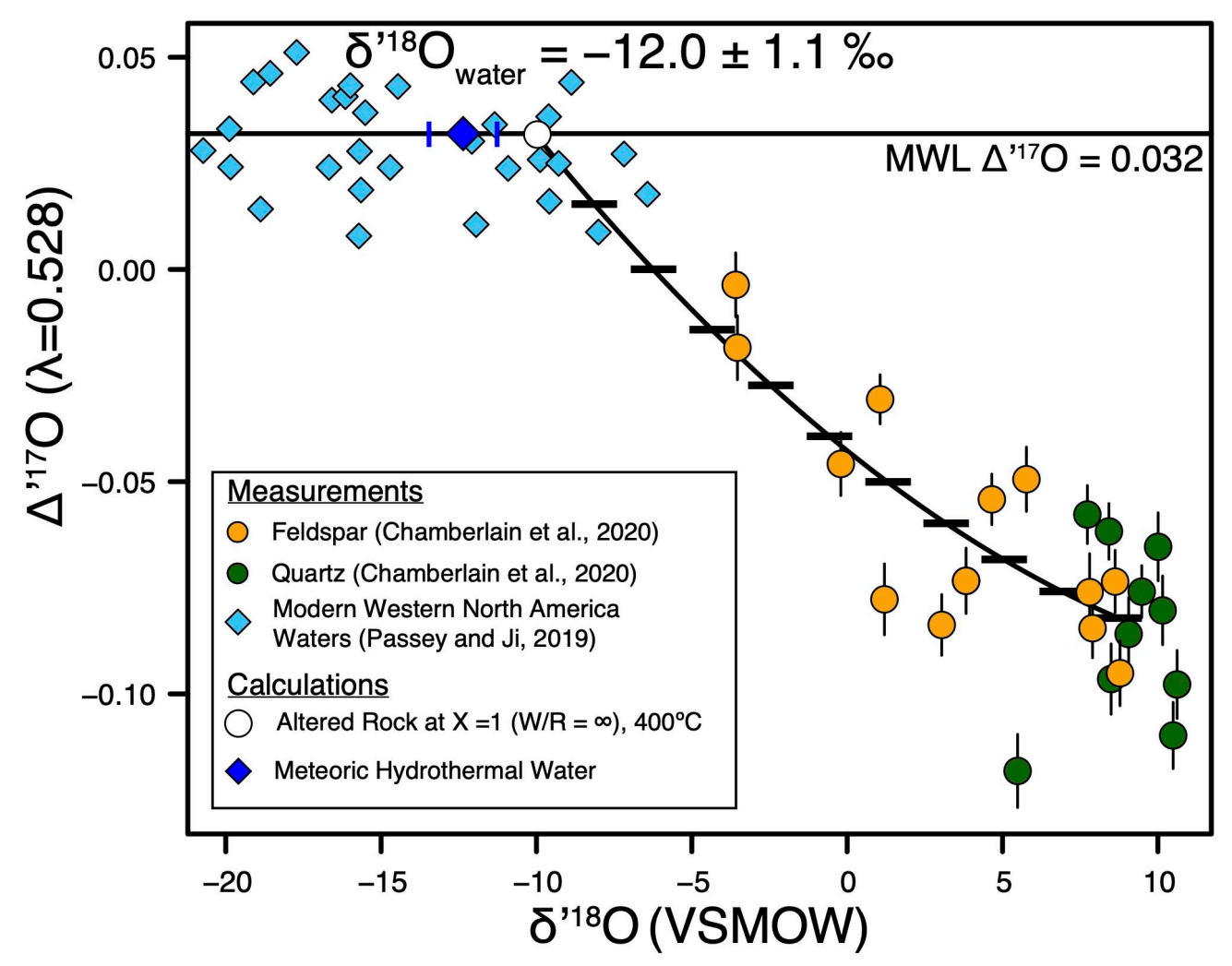

FIGURE 2 | The $\delta^{18} \mathrm{O}-\Delta^{, 17} \mathrm{O}$ alteration relationship (black line) of feldspar (modified from Chamberlain et al., 2020). The meteoric water line is from Passey and Ji (2019).

Chamberlain et al. (2020), it is difficult to reconcile these lower values of meteoric waters. There are three options. Either there was a major uplift event of the Cascades between the latest Eocene (37 Ma - this study) or the earliest Oligocene or the area where these glasses was sampled was higher (the Blue Mountains) than the Idaho Batholith, or these glasses have undergone later hydrogen exchange. However, no uplift event is observed in basins immediately east of the Cascades during this time period (Kukla et al., 2021) nor is there any other evidence that the Blue Mountains were that high. Indeed, the bulk of the uplift of the Cascades occurred in the Miocene as demonstrated by stable isotopic studies (Kohn et al., 2002; Takeuchi and Larson, 2005; Takeuchi et al., 2010).

Thus, we conclude that hydrogen isotope exchange most likely occurred in the Oligocene glasses analyzed by Bershaw et al. (2019). That hydrogen exchange does occur is clearly demonstrated in the experiments of Nolan and Bindeman (2013). They showed that rapid exchange of hydrogen occurs even at relatively low temperature while the oxygen of the glasses remains unchanged. There are experiments that suggest that treatment with hydrofluoric acid could remove the exchanged hydrogen (Cassel and Breecker, 2017), but this requires that their remains some pristine hydrogen in the volcanic glass. Additional evidence for hydrogen exchange in volcanic glass is also indicated in other studies. For example, triple oxygen isotope studies of Eocene chert in Nevada also give lower $\delta^{18} \mathrm{O}$ values than those determined by hydrogen isotope results of volcanic glasses (Ibarra et al., 2021). We suggest that the combined study of triple oxygen and hydrogen isotopes of multiple proxies could resolve this issue.

\section{IMPLICATIONS AND FUTURE DIRECTIONS}

There are a number of advantages to using triple oxygen isotopes for paleoaltimetry studies. First, the use of triple oxygen isotope paleoaltimetry allows the estimation of elevations of the crystalline cores of mountain belts. By targeting hydrothermal meteoric water hydrothermal systems, it is possible to determine elevations using oxygen isotopes alone. It is well known that meteoric waters penetrate deeply into the crust during orogenesis even in the absence of igneous activity (Templeton et al., 1998). Thus, this approach could be applied to hydrothermal quartz veins, fault zones, as well as low ${ }^{18} \mathrm{O}$ granites.

Second, as discussed above, triple oxygen isotopes can be used to test the reliability of hydrogen isotope results. This is particularly important because hydrogen isotope analyses are easier to collect and are more readily available than triple oxygen isotope analyses and each triple oxygen isotope analysis requires long count times $(1.5-2 \mathrm{~h})$ necessary to obtain the counting statistics for the needed level of precision. 
Third, although not the subject of this paper, triple oxygen isotopes on carbonates and chert (Ibarra et al., 2021) from paleolakes and clays and carbonates from paleosols can be used to test for evaporative effects and diagenesis. Evaporation of lake and soil water will increase the $\delta^{18} \mathrm{O}$ of the remaining water, thus obscuring paleoelevation estimates (e.g. Davis et al., 2009). These evaporative effects can be used in conjunction with well calibrated triple oxygen isotope systems such as silica- water (Sharp et al., 2016) and carbonate-water (Wostbrock et al., 2020) to retrieve the original meteoric water compositions. Moreover, it should also be possible to use triple oxygen to test for diagenesis as is frequently done using clumped isotopes (e.g., Methner et al., 2016).

\section{REFERENCES}

Abruzzese, M. J., Waldbauer, J. R., and Chamberlain, C. P. (2005). Oxygen and hydrogen isotope ratios in freshwater chert as indicators of ancient climate and hydrologic regime. Geochim. Cosmochim. Acta 69, 1377-1390. doi: 10.1016/j. gca.2004.08.036

Barkan, E., and Luz, B. (2005). High precision measurements of ${ }^{17} \mathrm{O} /{ }^{16} \mathrm{O}$ and ${ }^{18} \mathrm{O} /{ }^{16} \mathrm{O}$ ratios in $\mathrm{H}_{2} \mathrm{O}$. Rapid Commun. Mass Spectrom. 19, 3737-3742.

Bershaw, J., Cassel, E. J., Carlson, T. B., Streig, A. R., and Streck, M. J. (2019). Volcanic glass as a proxy for Cenozoic elevation and climate in the Cascade Mountains, Oregon, USA. J. Volcanol. Geothermal Res. 381, 157-167. doi: 10.1016/j.jvolgeores.2019.05.021

Capuano, R. N. (1992). The temperature dependence of hydrogen isotope fractionation between clay minerals and water: evidence from a geopressured system. Geochimica Cosmochimica Acta 56, 2547-2554. doi: 10.1016/00167037(92)90208-z

Cassel, E. J., and Breecker, D. O. (2017). Long-term stability of hydrogen isotope ratios of hydrated volcanic glass. Geochimi. Cosmochim. Acta 200, 67-86. doi: 10.1016/j.gca.2016.12.001

Cassel, E. J., Graham, S. A., and Chamberlain, C. P. (2009). Cenozoic tectonic and topographic evolution of the northern Sierra Nevada, California, through stable isotope paleoaltimetry in volcanic glass. Geology 37, 547-550. doi: 10.1130/ g25572a.1

Caves Rugenstein, J. K., and Chamberlain, C. P. (2018). The evolution of hydroclimate in Asia over the Cenozoic: a stable-isotope perspective. Earth Sci. Rev. 185, 1129-1156. doi: 10.1016/j.earscirev.2018.09.003

Chamberlain, C. P., Ibarra, D. E., Lloyd, M. K., Kukla, T., Sharp, Z. D., Gao, Y., et al. (2020). Triple oxygen isotopes of meteoric hydrothermal system-implications for paleoaltimetry. Geochem. Perspect. Lett. 15, 6-9. doi: 10.7185/geochemlet. 2026

Chamberlain, C. P., Poage, M., Craw, D., and Reynolds, R. (1999). Topographic development of the Southern Alps recorded by the isotopic composition of authigenic clay minerals, South Island, New Zealand. Chem. Geol. 155, 279-294. doi: 10.1016/S0009-2541(98)00165-X

Criss, R. R., and Taylor, H. P. Jr. (1983). An ${ }^{18} \mathrm{O} /{ }^{16} \mathrm{O}$ and $\mathrm{D} / \mathrm{H}$ study of Tertiary hydrothermal system in the southern half of the Idaho batholith. Geol. Soc. Am. Bull. 94, 640-663. doi: 10.1130/0016-7606(1983)94<640:aoadso> 2.0.co;2

Dansgaard, W. (1964). Stable isotopes in precipitation. Tellus 16, 436-468. doi: 10.3402/tellusa.v16i4.8993

Davis, S. J., Mix, H. T., Wiegand, B. A., Carroll, A. R., and Chamberlain, C. P. (2009). Synorogenic evolution of large-scale drainage patterns. Isotope paleohydrology of sequential Laramide Basins. Am. J. Sci. 309, 549-602. doi: 10.2475/07.2009.02

Delgado, A., and Reyes, E. (1996). Oxygen and hydrogen isotope compositions in clay minerals: a potential single mineral thermometer. Geochim. Cosmochim. Acta 60, 4285-4289. doi: 10.1016/s0016-7037(96)00260-8

Ehlers, T. A., and Poulsen, C. J. (2009). Influence of Andean uplift on climate paleoaltimetry estimates. Earth Planet. Sci. Lett. 281, 238-248. doi: 10.1016/j. epsl.2009.02.026

\section{AUTHOR CONTRIBUTIONS}

All authors contributed to the thinking and writing of this manuscript.

\section{FUNDING}

This research was funded by NSF EAR-1322084 and HeisingSimons' grants to CC. DI was supported by the UC Berkeley Miller Institute for Basic Research and UC President's Postdoctoral Fellowships. KM was supported by the Alexander von Humboldt Postdoctoral Fellowship.

Feng, R., Poulsen, C. J., Werner, M., Chamberlain, C. P., Mix, H. T., and Mulch, A. (2013). Evolution of Early Cenozoic topography, climate and stable isotopes of precipitation in the North America Cordillera. Am. J. Sci. 313, 613-648. doi: 10.2475/07.2013.01

Garzione, C. N., Quade, J., DeCelles, P. G., and English, N. B. (2000). Predicting paleoelevation of Tibet and the Himalaya from $\delta^{18} \mathrm{O}$ vs. altitude gradients in meteoric water across the Nepal Himalaya. Earth Planet. Sci. Lett. 183, 215-229. doi: $10.1016 / \mathrm{s} 0012-821 \mathrm{x}(00) 00252-1$

Graham, C. M. (1981). Experimental hydrogen isotope studies II: diffusion of hydrogen in hydrous minerals, and stable isotope exchange in metamorphic rocks. Contribut. Mineral. Petrol. 76, 216-228. doi: 10.1007/bf003 71961

Graham, C. M., Viglino, J. A., and Harmon, R. S. (1987). Experimental study of hydrogen-isotope exchange between aluminous chlorite and water and of hydrogen diffusion in chlorite. Am. Mineral. 72, 566-579.

Herwartz, D., Pack, A., Krylov, D., Xiao, Y., Muehlenbachs, K., Sengupta, S., et al. (2015). Revealing the climate of snowball Earth from $\Delta{ }^{17} \mathrm{O}$ systematics of hydrothermal rocks. Proc. Nat. Acad. Sci.U.S.A. 112, 5337-5341. doi: 10.1073/ pnas. 1422887112

Hren, M. T., Pagani, M., Erwin, D. M., and Brandon, M. (2010). Biomarker reconstruction of the early Eocene paleotopography and paleoclimate of the northern Sierra Nevada. Geology 38, 7-10. doi: 10.1130/g30 215.1

Hudak, M. R., and Bindeman, I. N. (2018). Conditions of pinnacle formation and glass hydration in cooling ignimbrite sheets from $\mathrm{H}$ and $\mathrm{O}$ isotope systematics at Crater Lake and the Valley of Ten Thousand Smokes. Earth Planet. Sci. Lett. 500, 56-66. doi: 10.1016/j.epsl.2018.07.032

Ibarra, D. E., Kukla, T., Methner, K. A., Mulch, A., and Chamberlain, C. P. (2021). Reconstructing past elevations from triple oxygen isotopes of, lacustrine chert: application to the Eocene Nevadaplano, Elko Basin, Nevada, USA. Front. Earth Sci. 9:169. doi: 10.3389/feart.2021.628868

Kohn, M. J., Miselis, J. L., and Fremd, T. J. (2002). Oxygen isotope evidence for progressive uplift of the Cascade Range. Oregon. Earth Planet. Sci. Lett. 204, 151-165. doi: 10.1016/s0012-821x(02)00961-5

Kukla, T., Ibarra, D. E., Caves Rugenstein, J. K., Golley, J., Mullins, C. E., Morange, D. Y., et al. (2021). High-resolution stable isotope paleotopography of the John day region, oregon, United States. Front. Earth Sci. 9:635181.

Kukla, T., Winnick, M. J., Maher, K., Ibarra, D. E., and Chamberlain, C. P. (2019). The sensitivity of terrestrial $\delta^{18} \mathrm{O}$ gradients to hydroclimate. J. Geophys. Res. Atmos. 124, 563-582. doi: 10.1029/2018jd029571

Lawrence, J. R., and Rashkes Meaux, J. (1993). "The stable isotopic composition of ancient kaolinites of North America," in Climate Change in Continental Isotopic Records. Geophysical Monograph Series, Vol. 78, eds P. K. Swart, K. C. Lohmann, J. McKenzie, and S. Savin 249-261. doi: 10.1029/gm078p 0249

McFadden, R. R., Mulch, A., Teyssier, C., and Heizker, M. (2015). Extension and meteoric fluid flow in the Wildhorse detachment, Pioneer metamorphic core complex, Idaho. Lithosphere 7, 355-366. doi: 10.1130/1429.1

Methner, K., Feibig, J., Umhoefer, P., Chamberlain, C. P., and Mulch, A. (2016). Eo-Oligocene proto-Cascades topography revealed by clumped $\left(\Delta_{47}\right)$ and 
oxygen isotope $\left(\delta^{18} \mathrm{O}\right)$ geochemistry (Chumstick Basin, WA, USA). Tectonics 35, 546-564. doi: 10.1002/2015TCC003984

Miller, M. F. (2002). Isotopic fractionation and the quantification of ${ }^{17} \mathrm{O}$ anomalies in the oxygen three-isotope system:An appraisal and geochemical significance. Geochimica Cosmochimica Acta 66, 1881-1889. doi: 10.1016/s0016-7037(02) 00832-3

Mix, H. T., Mulch, A., Kent-Corson, M. L., and Chamberlain, C. P. (2011). Cenozoic migration of topography in the North American Cordillera. Geology 39, 87-90. doi: 10.1130/g31450.1

Mulch, A., Graham, S. A., and Chamberlain, C. P. (2006). Hydrogen isotopes in Eocene river gravels and paleoelevation of the Sierra Nevada. Science 313, 87-89. doi: $10.1126 /$ science. 1125986

Mulch, A., Sarna-Wojcicki, A. M., Perkins, M. E., and Chamberlain, C. P. (2008). A Miocene to Pleistocene climate and elevation record of the Sierra Nevada. Proc Nat. Acad. Sci. 105, 6819-6824. doi: 10.1073/pnas.0708811105

Mulch, A., Teyssier, C., Cosca, M. A., Vanderhaeghe, O., and Vennemann, T. (2004). Reconstructing paleoelevation in eroded orogens. Geology 32, 525-528. doi: $10.1130 / \mathrm{g} 20394.1$

Nolan, G. S., and Bindeman, I. N. (2013). Experimental investigations of rates and mechanisms of isotope exchange $(\mathrm{H}, \mathrm{O})$ between volcanic ash and isotopicallylabeled water. Geochim. Cosmochim. Acta 111, 5-27. doi: 10.1016/j.gca.2013. 01.020

O’Neil, J. R., and Kharaka, Y. K. (1976). Hydrogen and oxygen isotope exchange reactions between clay minerals and water. Geochim. Cosmochim. Acta 40, 241-246. doi: 10.1016/0016-7037(76)90181-2

Pack, A., and Herwartz, D. (2014). The triple oxygen isotope composition of the Earth mantle and understanding $\Delta 17 \mathrm{O}$ variations in terrestrial rocks and minerals. Earth Planet. Sci. Lett. 390, 138-145.

Passey, B. H., and Ji, H. (2019). Triple oxygen isotope signatures of evaporation in lake waters and carbonates: a case study from the western United States. Earth Planet. Sci. Lett. 518, 1-12. doi: 10.1016/j.epsl.2019.04.026

Poage, M. A., and Chamberlain, C. P. (2001). Empirical relationships between elevation and the stable isotope composition of precipitation and surface waters: considerations for studies of paleoelevation change. Am. J. Sci. 301, 1-15. doi: 10.2475/ajs.301.1.1

Poulsen, C. J., and Jeffery, M. L. (2011). Climate change imprinting on stable isotopic compositions of high-elevation meteoric water cloaks past surface elevations of major orogens. Geology 39, 595-598. doi: 10.1130/G3 2052.1

Quade, J., Garzione, C., and Eiler, J. (2007). "Paleoelevation reconstruction using pedogenic carbonates," in Paleoaltimetry: Geochemical and Thermodynamic Approaches: Reviews in Mineralogy and Geochemistry, Vol. 66, ed. M. J. Kohn 53-87. doi: 10.1515/9781501508608-005

Rowley, D. B., Pierrehumbert, R. T., and Currie, B. S. (2001). A new approach to stable isotope-based paleoaltimetry: implications for paleoaltimetry and paleohypsometry of the high Himalaya since the Late Miocene. Earth Planet. Sci. Lett. 188, 253-268. doi: 10.1016/s0012-821x(01)00324-7

Sharp, Z. D., Gibbons, J. A., Maltsev, O., Atudorei, V., Pack, A., Sengupta, S., et al. (2016). A calibration of the triple oxygen isotope fractionation in the $\mathrm{SiO}_{2}-$ $\mathrm{H}_{2} \mathrm{O}$ system and applications to natural samples. Geochim. Cosmochim. Acta 186, 105-119. doi: 10.1016/j.gca.2016.04.047

Sharp, Z. D., Masson, H., and Lucchini, R. (2005). Stable isotope geochemistry and formation mechanisms of quartz veins: extreme paleoaltitudes of the central Alps in the Neogene. Am. J. Sci. 305, 187-219. doi: 10.2475/ajs.305 3.187

Sharp, Z. D., Wostbrock, J. A. G., and Pack, A. (2018). Mass-dependent triple oxygen isotope variations in terrestrial materials. Geochem. Perspect. Lett. 7, 27-31. doi: 10.7185/geochemlet.1815

Takeuchi, A., Hren, M. T., Smith, S. V., Chamberlain, C. P., and Larsen, P. B. (2010). Pedogenic carbonate carbon isotopic constraints on paleoprecipitation: evolution of desert in the Pacific Northwest, USA, in response to topographic development of the Cascade Range. Chem. Geol. 277, 323-335. doi: 10.1016/j. chemgeo.2010.08.015

Takeuchi, A., and Larson, P. B. (2005). Oxygen isotope evidence for the late Cenozoic development of an orographic rain shadow in eastern Washington. USA: Geology 33, 313-316. doi: 10.1130/G21335.1

Taylor, H. P. Jr. (1974). The application of oxygen and hydrogen isotope studies to problems of hydrothermal alteration and ore deposition. Econ. Geol. 69, 843-883. doi: 10.2113/gsecongeo.69.6.843

Taylor, H. P. Jr. (1978). Oxygen and hydrogen isotope systematics of plutonic granitic rocks. Earth Planet. Sci. Lett. 38, 177-210. doi: 10.1016/0012-821x(78) 90131-0

Templeton, A. S., Chamberlain, C. P., Koons, P., and Craw, D. (1998). Tectonically driven mixing between midcrustal fluids and surface-derived waters during recent uplift of the Southern Alps, New Zealand. Earth Planet. Sci. Lett. 154, 73-92. doi: 10.1016/s0012-821x(97)00143-x

Winnick, M. J., Chamberlain, C. P., Caves, J., and Welker, J. M. (2014). Quantifying the Isotopic "Continental Effect". Earth Planet. Sci. Lett. 406, 123-133. doi: 10.1016/j.epsl.2014.09.005

Winograd, I. J., Szabo, B. J., Coplen, T. B., Riggs, A. C., and Kolesar, P. T. (1985). Two-million record of deuterium depletion in Great Basin ground waters. Science 227, 519-522. doi: 10.1126/science.227.4686.519

Wostbrock, J. A. G., Brand, U., Coplen, T. B., Swart, P. K., Carlson, S. J., Brearley, A. J., et al. (2020). Calibration of carbonate-water triple oxygen isotope fractionation: Seeing through diagenesis in ancient carbonates. Geochim. Cosmochim. Acta 288, 369-388. doi: 10.1016/j.gca.2020.07.045

Zakharov, D. O., Bindeman, I. N., Slabunov, A. I., Ovtcharova, M., Coble, M. A., Serebryakov, N. S., et al. (2017). Dating the Paleoproterozoic snowball Earth glaciations using contemporaneous subglacial hydrothermal systems. Geology 45, 667-670. doi: 10.1130/g38759.1

Zakharov, D. O., Bindeman, I. N., Tanaka, R., Frioleifsson, G. O., Reed, M. H., and Hampton, R. L. (2019). Triple oxygen isotope systematics as a tracer of fluids in the crust: a study from modern geothermal systems of Iceland. Chem. Geol. 530:119312. doi: 10.1016/j.chemgeo.2019.119312

Conflict of Interest: The authors declare that the research was conducted in the absence of any commercial or financial relationships that could be construed as a potential conflict of interest.

Copyright (c) 2021 Chamberlain, Ibarra, Kukla, Methner and Gao. This is an openaccess article distributed under the terms of the Creative Commons Attribution License (CC BY). The use, distribution or reproduction in other forums is permitted, provided the original author(s) and the copyright owner(s) are credited and that the original publication in this journal is cited, in accordance with accepted academic practice. No use, distribution or reproduction is permitted which does not comply with these terms. 